\title{
Festival and the City: Performativity of Sexual acts in public spheres
}

Dundjerovic/Martínez Sánchez 


\section{INTRODUCTION}

In this paper, we address the perception of sexual activities in public spaces and how they become aesthetic, social and cultural intervention once expressed through and embodied within performative events (theatre, street performance, carnival, festival, rave etc). A substantial amount of research has been done on the relation between sexuality and gender about public spaces, and influence of civic and urban identity on public expression of sexuality and gender. We will look at the invented rituals establishing sexuality within a context of performativity through relationships with public spaces. As the case studies, we will use the works of theatre companies La Fura dels Baus and Teatro Oficina. To set up the set of relationships between inside and outside, we will borrow a useful concept on 'spheres' from the German philosopher Peter Sloterdijk to look at the public space as a system of spheres where a different set of rules apply enabling actions to take place. These performances in urban contexts, as well as some festivals and particularly carnivals, become a way of the staging of sexual acts in public space, in opposition to the dominant narrative of private - domestic space. We will look at how collectiveness and civic spaces become essential elements of this phenomenon and its relevance in our contemporary reality as an element of subversion of social structures. We will also examine performative events where sexual acts as a language of human relationship in public spaces bringing intimacy.

\section{SPHERES - FROM PUBLIC TO PRIVATE SPACES}

According to Foucault (1976) sexual expressions has moved from the public spaces into domestic, into the privacy of the house with the rise of the $19^{\text {th }}$ century bourgeoisie. At the beginning of XVII century 'sexual practices had little need of secrecy; words were said without undue reticence, and things were done without too much concealment; one had a tolerant familiarity with the illicit' (Foucault, 1976:3). For Foucault, this was an open and shameless transgression that took place in the public spaces as well as in collectively shared dwellings, as in large families sleeping in one room. However, with the development of Victorian Bourgeouise, sexuality was carefully confined into the secrecy of home, a story that is supported even today. Foucault asserts that 'on the subject of sex, silence became the rule" (1976:3). The secrecy became the model imposed by the couples of themselves. 'Sexuality was acknowledged in social space as well as at the heart of every household, but it was utilitarian and fertile one: the parents' bedroom' '(1976:3). The passion, which drives sexuality, is seen in traditionally rationalist European philosophy (Descartes and Hobbs) as served by a reason, but in opposition to it and thus having dangerous effect on society. Passion is product of mind that extends to body actions and if unstructured it threatens the order. Foucault recognizes proximity to which mind and body were kept long before $18^{\text {th }}$ century, where passions were approached as temporary madness. By positioning madness as disease that can affect and connect mind and body he observes that 'the possibility of madness is therefore implicit in the very phenomenon of passion.' (2002:83). Quarantining passion was important part of preservation of structures that impose itself on urban social matrix of a city, as much as festivals became important part of disruption and liberation of passions. In this way , sexuality becomes object of control and implementation of power. 
Bakhtin (1984:188) position the breakage within the social norms allowing private to appear within a public, as a fact of liberation and subversion towards the social structures. Such speech forms liberated from social rules, implicite hierarchies, and prohibitions of established idiom, become themselves a peculiar argot and create a particular collectivity, a group of people initiated in familiar intercourse, who are frank and free in expressing themselves verbally. The marketplace crowd was such a collectivity, especially the festive, carnivalesque crowd at the fair. (Bakhtin, 1984:188) When social structures are abolished, the disorder appears. Performativity creates temporarily believe that there is a possibility or potentiality, suspending structures allowing disorder. There are situations in which social rules disappear leading to chaos and state of confusion where one of the first things that arise are violence and sexual acts as primary impulses.
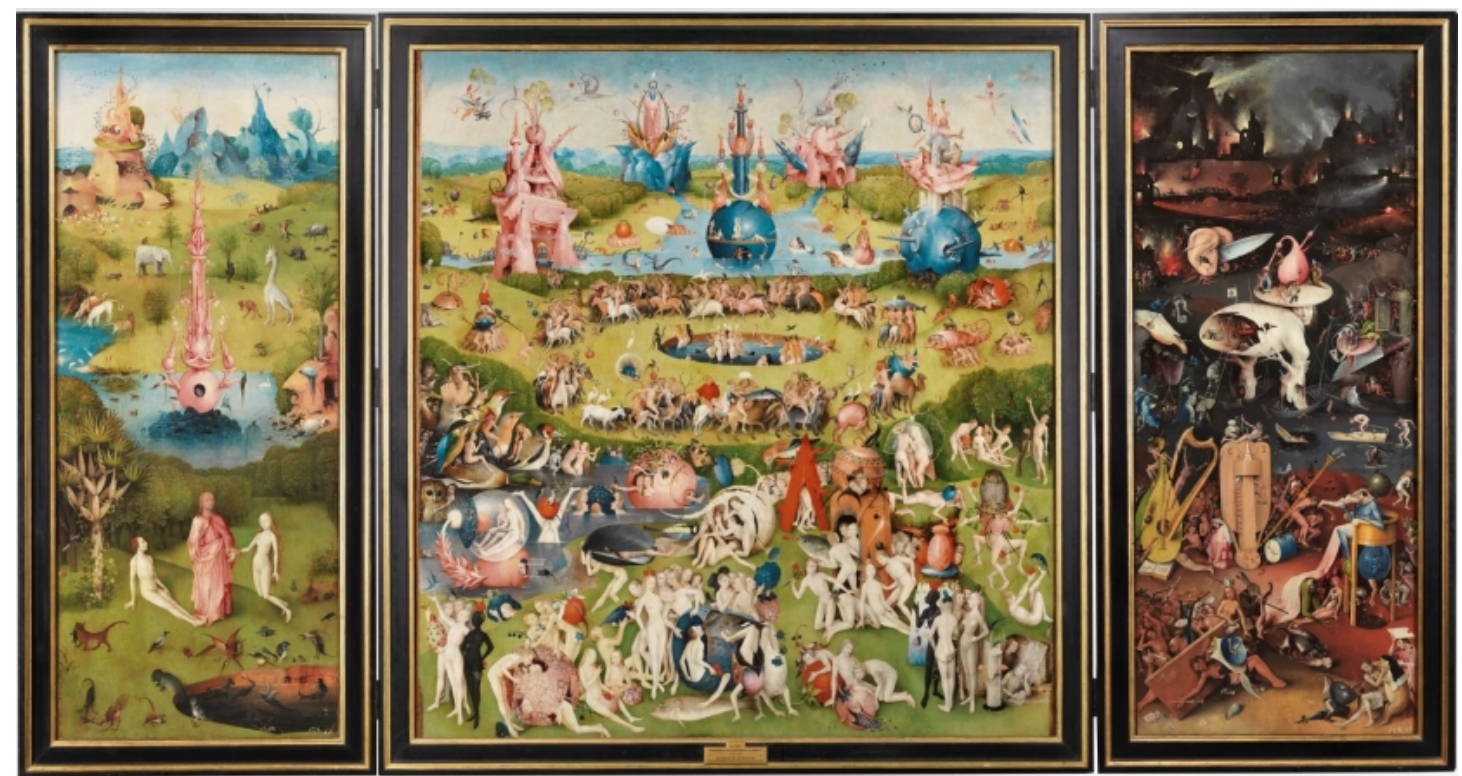

Fig.02 The garden of earthly delights by Hieronymus Bosch (1503-1515)

De Certeaux ( 1992;58) conception of the 'unnambale other place' offers in reading of Hieronymus Bosch's 'The Garden of Earthly Delights' notion of differences , where composed spaces have meaning only in relation to one another. Taking this idea further Sloterdijk's reference human action within spheres, He points out that:

Because living always means building spheres, both on a small and a large scale, humans are the beings that establish globes and look out into horizons. Living in spheres means creating the dimension in which humans can be contained. Spheres are immune-systemically useful space creations for ecstatic beings that are operated upon by the outside. (Sloterdijk, 2011:28).

The Bosch's painting is used as a central image by Sloterdijk to explain his concept of spheres by pointing to a detail of a couple within a bubble. In this painting, there are multiple actions taking place simultaneously, but there are some bubbles which contain the most intimate acts. There are two couples enclosed in bubbles, a physical representation of the sphere that is configured as a boundary between the exterior and the interior, the environment that is created by them and belongs to them, with the particular conditions that they create within their action. It is a visual representation of 
a sphere. It shows how spheres emerge from the contexts created, which is linked to the relationship between them.

The public approach to activities that could be seen as sexual act are confined in the secrecy of a private sphere and away from a public sphere, they remains dominant narrative late into the mid 20th century. For example, in the 1950s in Spain, there were specific legal regulations about sexually related activities in public spaces. There is a copy of an original document that was shared on Facebook this year with apparently ironic undertone stating the fees for physical acts that were considered inappropriate in a public space in Sa Pobla, in Spain during Franco's dictatorship (1957). For example, "putting the hand on the top tie of the leg is 1000 pesetas' (around $£ 3000$ in today's money). In the actual intercourse, described as "with that in and out of that," the charges went to 4000 pesetas (£12000). Apparently, the most expensive fee was for anal sex, described as "that that goes behind that" which was 5000 pesetas (£15000). Although the document has a signature by the mayor of the town hall of Sa Pobla, its authenticity has doubts claiming that it was a parody of the repressiveness of any form of intimacy in public spaces.

In the $70 \mathrm{~s}$ and $80 \mathrm{~s}$ the discourses about public spaces and sexuality have been dominated by the gendered and sexual identity debates and in particular gay and lesbian expression connected to what is banned and not acceptable within the public space. Pat Califia $(1982,71)$ in a seminal book 'Public Sex' writes that liberalization in 1980s of the sex law would be much needed improvement, warns that there should be careful definition of term ' sex in private'. Narrow definition of privacy could lead into exclusion of being gay or having sex outside monogamous relations. State control and penalization of unapproved sexual acts is relevant in a document written at the time when homosexual sex between adults was not legal in England in the 19607:

....What they proposed ( lawmakers) was partial retreat of the law from the regulation of the individual behavior...so male homosexuality in private should be decriminalized... But the logic of the distinction between private and public behavior was that the legal penalties for public displays of sexuality could be strengthened at the same time as private behavior was decriminalized... (Weeks, J., 1981:242-244).

Califia argues that there is a direct relation between the legal control of private and public behaviour and that "the state always wishes the zone of privacy to be as narrow as possible" (1994:74).

Women have spread the use of the female body in public spaces as an object of protest. Although nudity itself doesn't imply necessarily a sexual act, the actions developed in these protests involve sexual liberation and, therefore they become sexual acts. Just bringing the naked female body in public spaces has subversive and sexual connotations, as Rose Weitz argues: 'Beginning with the earliest written legal codes, and continuing nearly to the present day, the law typically has defined women's bodies as men's property' (Weitz, R., 1998:3). Feminists present their bodies as an act of liberation from the patriarchy, where males have traditionally been in power. This is what is called body protest, and it is defined by the 'organic 
feminists' response to the widespread sexual profiling that they encounter daily in the social, political and familial spheres of their lives' (Alexandre, M., 2006:178).

Feminist activists revert sexuality and gender from private into public in addressing violence against women. They have vindicated their positions through performative events that were used as activist tools against the social or, in this case, political structures seen as oppressive. An example of this was the protest against femicide staged by Fuerza Artística de Choque Comunicativo (Artistic Force of Communicative Shock, or FACC) in front of the president's palace in Buenos Aires. A group of naked women met at the Plaza del dos de Mayo and removed her clothes silently and climbing on top of each other creating a mountain made of naked bodies. Finally, they got to their feet and started screaming using orgasmic screams that lasted around a minute. Here sexual acts - with its performativity - were used as a tool of protest by setting up a new context within a public space.

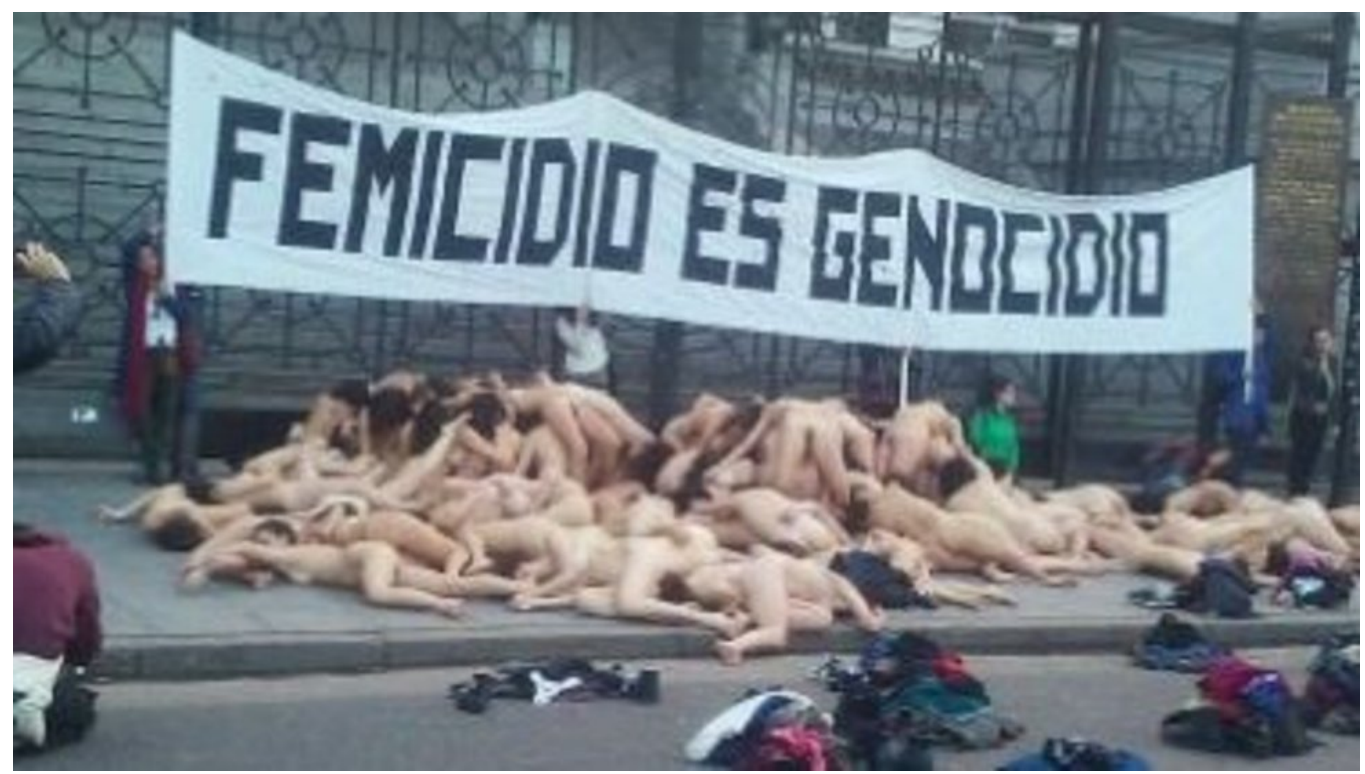

Fig.01 Protest against femicide staged by Fuerza Artística de Choque Comunicativo (Artistic Force of Communicative Shock, or FACC)

At the present moment, in the late second decade of 21st century, sexual acts within the public sphere are defined by the context in which they appear, relations they establish with outside conditions, and the social structures they are subverting. However, in performativity in public spheres, the central point remains that sexual acts are in friction with an outside condition, and established norms.

We can see it in war situations where people who have been previously completely integrated into the social scheme start acting differently. It is interesting how the acknowledgment of the rules and suspension of the rules is what makes us behave as social beings. In Golding's seminal novel Lord of the flies (1954), it is visible how brutality and barbarism can become institutionalised in society. Written after the 
Second World War, the book reflected on the evil that became commonplace, presenting war as a catalyst to release present evil (Foster, 10). In a suspension of the existing structure the new structure arises, which is the point of liberation, to what Bakhtin refers in his term carnivalesque. (quote from Bakhtin) As a result of this disorder and subversion, new conditions are established. There is a whole new environment that is set up, which regulates the behavior within the new circumstances.

Sexual activities presented as performative events within public sphere are dependant on the context in which they are situated. Regarding performativity, this implies that the sphere can also be used to design performance context. Performativity makes the boundaries more flexible and allows space for an eruption of unpredictable behaviours. As a vehicle for sexual acts within a public sphere, performativity has the same function as the festival or carnival within the Bakhtin context of suspension of norms and the establishment of air conditioning environment as pointed by Sloterdijk.

Spheres are closed systems whose construction and calibration are through living in real coexistence and participatory relations.The symbolic air conditioning of the shared space, as a closed environment, is the primal production of every society. Indeed-humans create their micro-climate; not according to free choice, however, but under preexisting, given and handed-down conditions, politicaly contexualised.

(Sloterdijk, 2011: 46-48)

\section{SEXUAL ACTIVITIES AND PERFORMATIVITY: CASE STUDIES}

The musical ritual spectacle Macumba Antropofaga (2008) by Teatro Oficina in Sao Paulo that was performed from July to September 2017. The performance is a satire on Brazilian and global politics contrasting the elements from Modernist poet Oswald de Andrade's Manifesto Antropofagico (1928). Zé Celso directed and devised performance with a group of actors. One of the founding fathers of anthropophagic theatricality, director-author Zé Celso established, with Teatro Oficina, procedures and approaches to performance practices that put into effect anthropophagic philosophy. Theatrical adaptations by cannibalizing other traditions and texts in a ceremonial expression in which performance is a ritual involving the audience became a pillar of Zé Celso's performance authorship as a reference point for the generation of Brazilian encenadores profoundly influenced by his theatricality that followed in the 1990s and afterward.

The collaborative creative process and Brazilian director-authors expression of artistic anthropophagi in the creation of performance are important in the relationship with audiences regarding carnivalesque practices, and the performativity that is central to ceremony and festivals.

In Macumba Antropofaga (Teatro Oficina, Sao Paulo, 2017), a 5-hour long performance, displays a clear process of how contextualization and organising of conditions invoke change in the accepted social behaviour. The dramaturgy of sexual acts is being set up from the beginning of the performance by creating a space of intimacy between audience and performers. The first part of the performance takes the 
audience from the space of Teatro Oficina through a procession in the streets of Sao Paulo, in the surrounding area. This procession was integrated into the everyday life of the streets with their inhabitants - both in regulated buildings and favelas. Some of the people who lived in the favela that was located under a nearby bridge joined the procession breaking the boundaries between performance and everyday life. In the creation of intimacy, the audience role was inverted, and they were made part of a spectacle, as people on the street who observed the procession of audience and actors became the spectators. This method created a public sphere in which performers and audience coexisted together in response to an outside environment, which was the street.

The procession configured in the audience an initial feeling of collectiveness, of a group that is going through an experience that others don't know about. This initial stage was essential to build up the context - or the 'performative sphere' regarding Sloterdijk - in which the performance will develop.

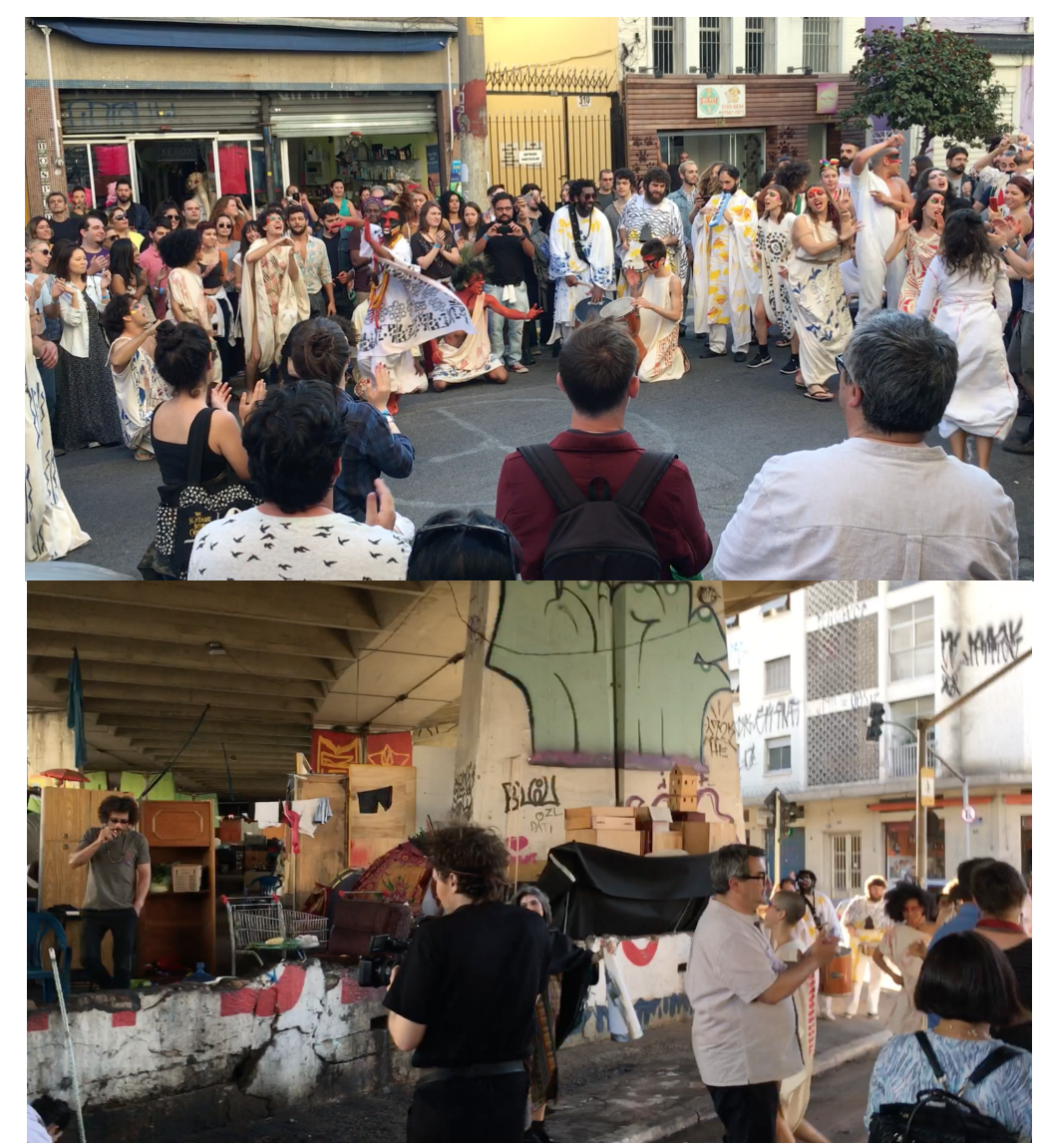

Fig.03/04 Macumba Antropofaga. Procession. Teatro Oficina, Sao Paulo (Brazil). 15th July 2017

Once back in the theatre space, the creation of collectiveness the bondage between the performers and the audience became stronger. The new sphere is set up inside Teatro Oficina where performers invited individual audience members to join the procession in the performance space where later they will encourage them to take off their clothes. This behaviour is triggered by the gradual introduction of the new conditions and rules that performers have set up within the 'sphere.' 


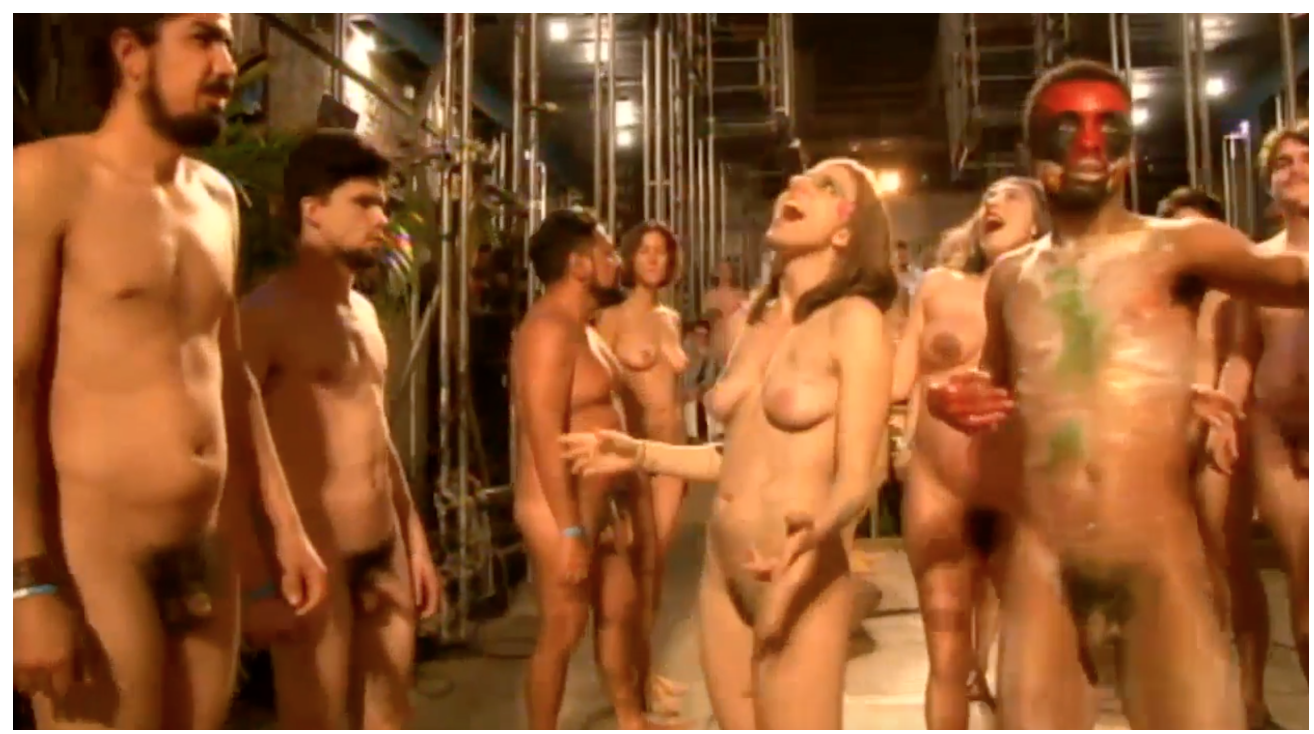

Fig.05 Macumba Antropofaga. Ritual. Teatro Oficina, Sao Paulo (Brazil). 15th July 2017

The conditions of street procession, rituals and collectiveness led to sexual acts within an environment that was performative. The actions that took place were not real, were part of performative events in which the audience were performers. By involving an audience in sexual acts, they were liberated through performativity from social norms, which became dispensed within the established public sphere; the sphere facilitated the new behaviour.

La Fura dels Baus, a Spanish theatre company - formerly an independent street theatre company - based in Barcelona, brings provocative and radical acts into public spaces. Since 1979, La Fura creates radical mise-en- scenes making interventions into public spaces and alternative theatre spaces - a butchery, an abandoned mortuary... etc. - creating situations in which the audience is exposed to violence, nudity and sexual acts in the central public locations of the cities. They developed their performative language - Furan Language - that emerges through collectiveness with audience working in public spaces. The performance language of la Fura creates meanings which are not contained within themselves but are acts of expression towards the exterior, translated into the provocative, violent and sexual acts that they stage. Over the years, la Fura has worked in different performance locations; however, they preserved characteristics of an outdoor spectacle, similar to working in public spaces. 


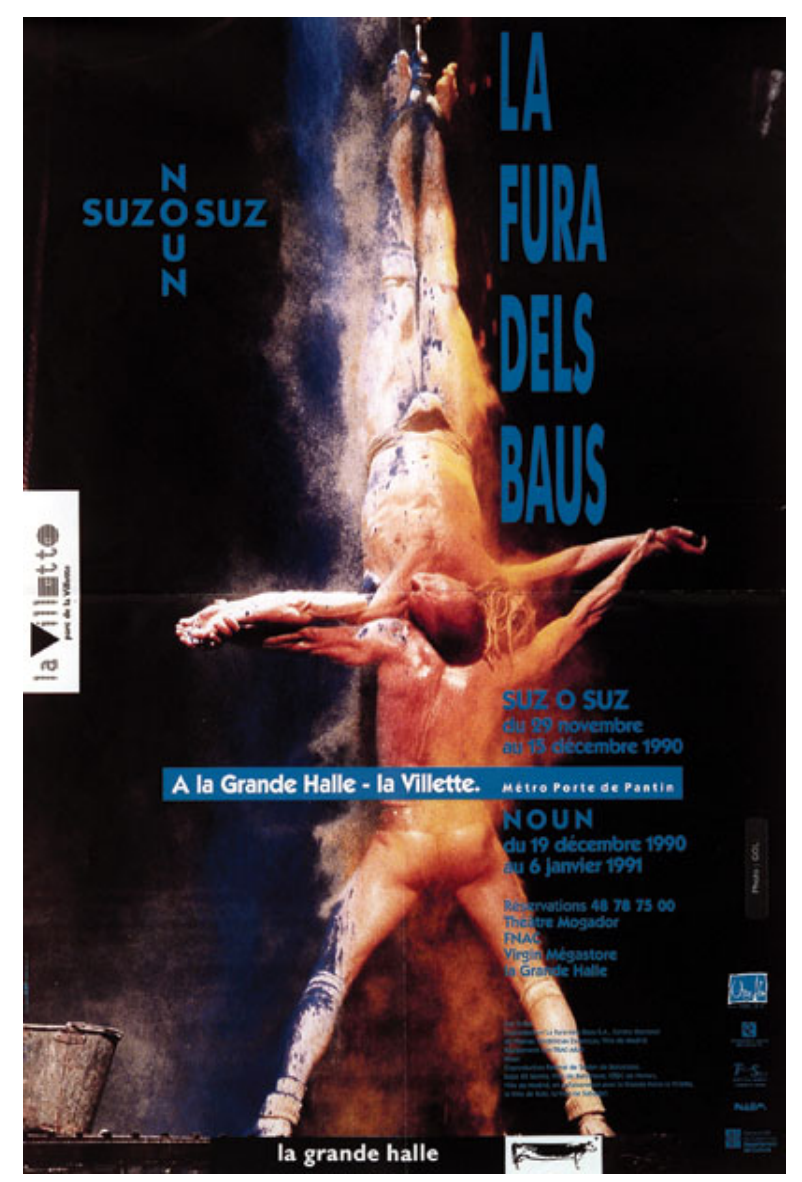

Fig.06 Suz o Suz. La Fura dels Baus

The landmark production from 1985 Suz o Suz, established their performativity as ritualistic. The company took an abandoned mortuary in the centre of Madrid, because of its spatial characteristics (La Vanguardia, 1/09/1985), therefore making it into a site-specific performance event, linking the public use of space with performative events. This sensitivity towards space is inherent to all their work, which makes all their performances site-specific; even if they don't have a site, they need to create the site. The scale of their sets in their productions is exact; there is also a constant on this, there is always an urban scale, associated with the spaces where they developed their first street theatre performances.

In Suz o Suz the performers, naked under white shirts, throw objects and chase the audience, at the same time as some violent actions are staged. This sexual act is presented in front of an active audience, that is forced to move around the space, and accept those conditions as normal, being part of the new performative sphere.

Typically their performative elements consist of large movable physical objects, platforms, giant puppets, and multimedia projections. Even if they are performing indoors, the audiences are placed as if they were in a public square. For example, in La degustación de Titus Andronicus (2010), the audience surrounds scenes in different locations that are presented fragmented in the space. There is a resemblance of the procession in Spanish medieval festival, where the action would move around the public square interacting with the audience. La Fura recreates an open space indoors. The audience is physically involved in the act of observing, being aware of witnessing the act and taking part in performativity in the public sphere. They use the vocabulary of nudity, violence and engaging in sexual acts within the proximity of 
audience, which validates and become the accomplice to the subsequent performative events.

In the productions of La Fura dels Baus, the audience plays a vital role: the audience presence is an essential part of a ritual, often being central performance event: they become present, they are aware of their role as an audience. As in the previous case study, they set up through performativity the conditions within which some specific actions will take place.

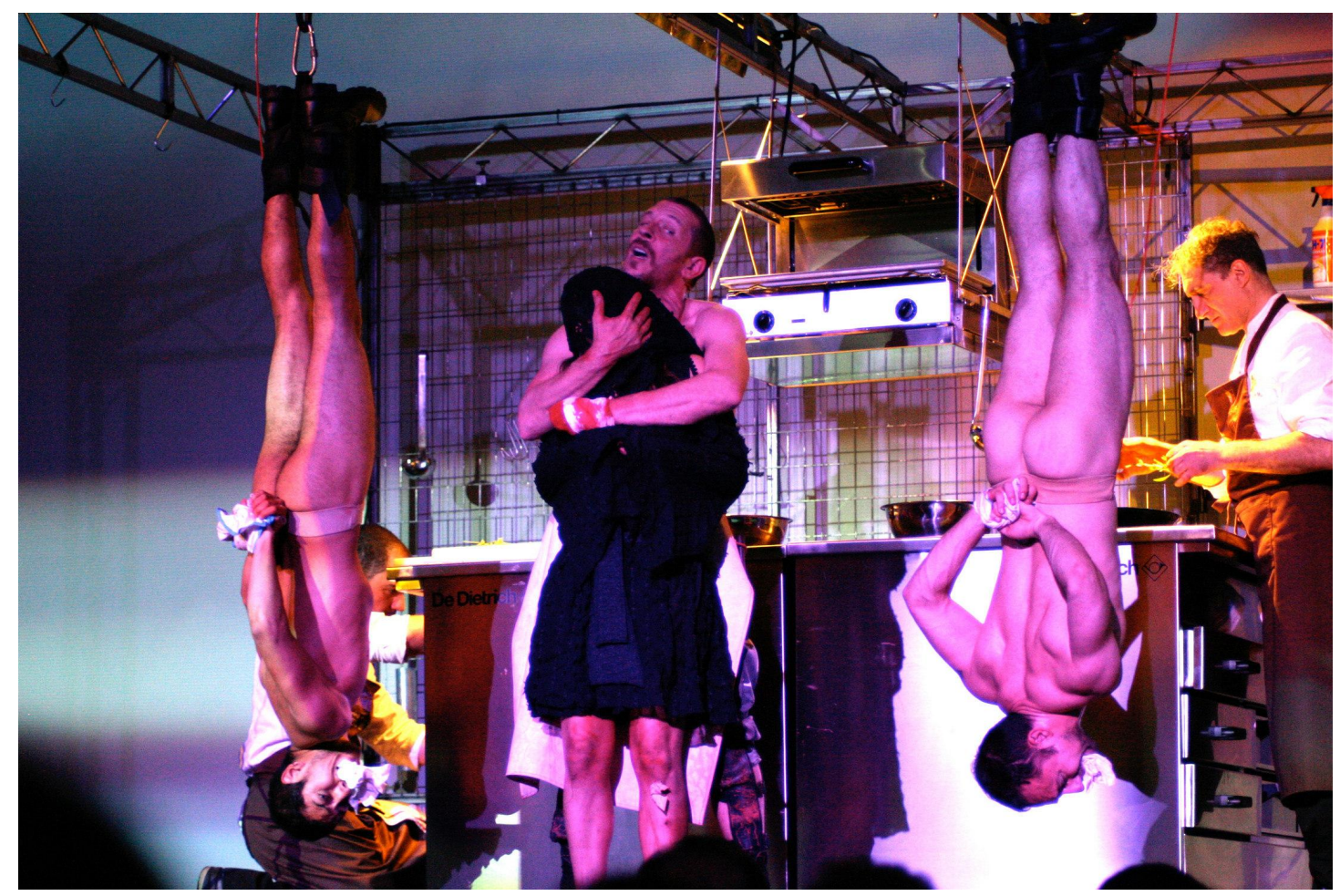

Fig.08 La degustacion de Titus Andronicus. La Fura dels Baus

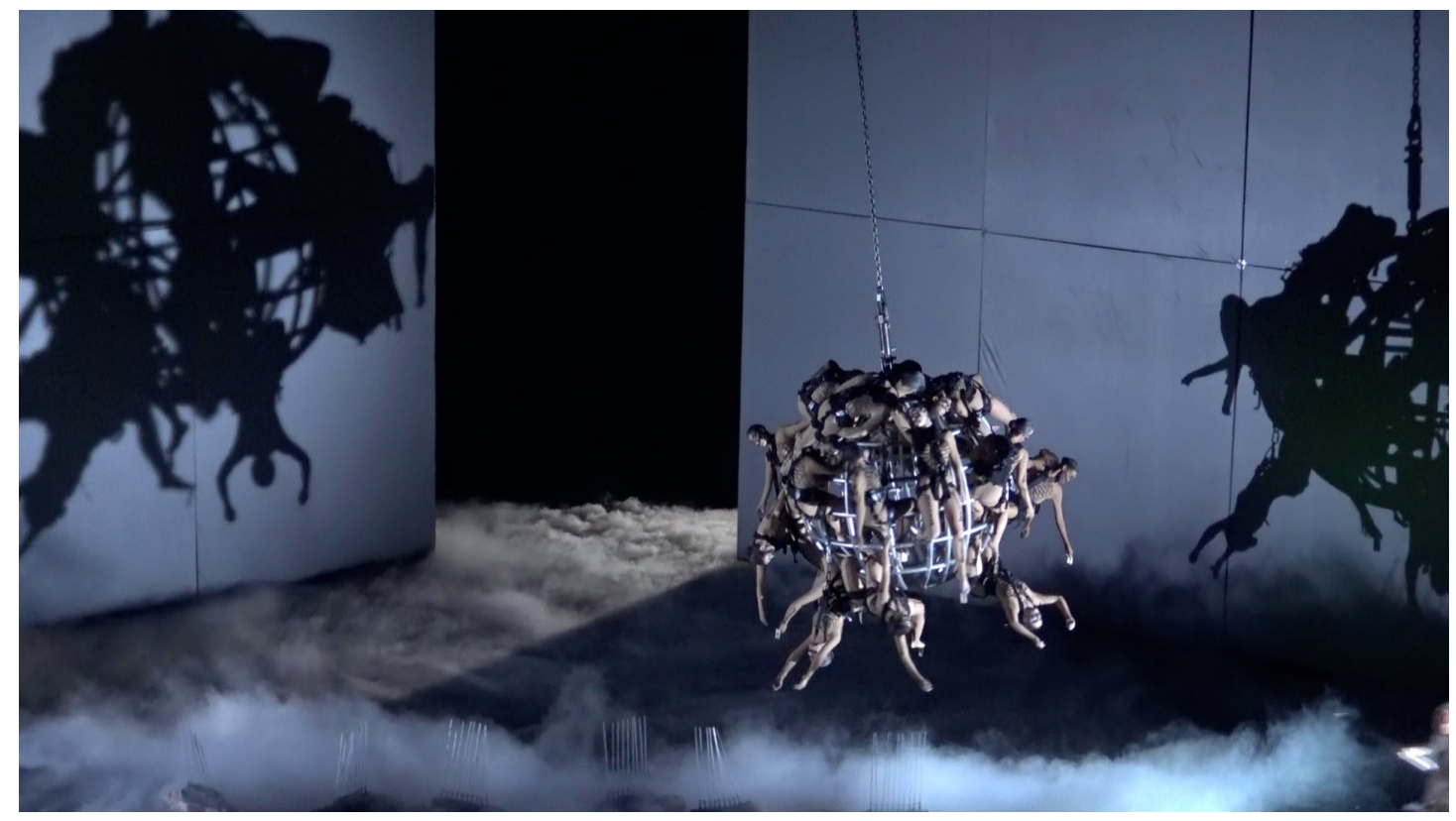


The setting for Die Walkure - part of Wagner's Der Ring des Nibelungen - was composed through fragmented space inhabited by hydraulic machines, cranes, scaffolding and visual projections. For example, they created a pendulum that oscillates on stage where naked bodies were attached to a metallic sphere. They represented the heroes that died in the battle; there is an association of violence and nudity which is staged in a public arena. Violence, sex, and nudity are for La Fura an essential part of the performative environment; they define the air conditioning established within the environment of the sphere.

\section{CONCLUSIONS}

When performing sexual acts in public spaces, there is a restriction that defines and contextualise the events. Performativity arises, as a way of developing public spheres that justify some specific acts to be performed that otherwise would never be allowed. The possibility of sexual acts to become emerging disruptor and a subversion of outside norm within a public space requires a departure from consciousness and establishing a context through performativity.

In the performance activism piece by Fuerza Artística de Choque Comunicativo (Artistic Force of Communicative Shock, or FACS), the performativity comes out of a context that reflects a real-life situation. However, the activism demands visibility, so the group does not operate from a marginal location regarding mainstream, it radically relies on the performance actions, as chosen space is institutional - the front façade of the major's residency. Both theatre companies, La Fura dels Baus and Teatro Oficina function in opposition to mainstream and visible public spaces, they create public spheres within marginalised contexts. Their context is created through performativity setting up and reworking rituals involving audience within the framework that they developed in which sexual activities take place in different performance spaces.

Regardless if they are outdoor or indoor, the spaces are functioning as public spheres that are interconnected and inclusive of performers and the audiences. There is a process in performance through which the audiences are initiated and introduced to ritual and performativity creates specific conditions for that collectiveness to take place. In the work of both companies, they perform in public open spaces, so there is a conscious selection of sites that will have an impact on the actions performed. The expression of sexual acts in public spaces as part of performative events is defined by contexts in which they are placed functioning within the spheres that contain human actions. 


\section{BIBLIOGRAPHY}

Alexandre, M. (2006), Dance halles, masquerades, body protest and the law: the female body as a redemptive tool against Trinidad's gender-biased laws. pp178 Duke journal of gender law \& policy 13:177.

Andrade, Oswald de. (1928)"Manifesto antropofago." Revista de Antropofagia (São Paulo, Brasil), no.1 : 3,7 . Accessed on https://icaadocs.mfah.org/icaadocs/THEARCHIVE/FullRecord/tabid/88/doc/771303/1 anguage/en-US/Default.aspx

Bathkin, M., (1984) Rabelais and his world. Indiana University Press: USA.

Califia, P. (1994) Public sex. The culture of radical sex. Cleis Press Inc.: Pittsburgh, Pensylvania (USA).

Dundjerovic, A. (2017) "Introduction: Collaborative Theatre Practices in Brazil' eds Dundjerovic, Ramos (2017) Brazilian Collaborative Theatre McFarland Inc. Jefferson, USA.

Foster, S.W. (2002). Lord of the Flies. York Press. 322 Old Brompton Road: London SW5 9JH.

Foucault, M. (1976) History of sexuality. Volume I: an Introduction. Pantheon books: New York.

Golding, W. (1954) Lord of the Flies. Faber and Faber. London, UK.

Hubbard, P. (2001) 'Sex Zones: Intimacy, Citizenship and Public Space', Sexualities, Sage Journals Vol. 4, Issue1 : 51-71.

Lehmann, HT. (2006) Postdramatic Theatre. New York:Routledge.

Oddey, A. (1996) Devising Theatre: A Practical and Theoretical Handbook. Oxon, Reino Unido: Psychology Press.

Pearson, P.M. (2010) Site-Specific Performance. Houndmills, Basingstoke, Hampshire, New York: Palgrave Macmillan.

Saumell, M. (2007) 'La Fura dels Baus: Scenes for the twenty-first century' issue 3: Catalan Theatre 1975-2006: Politics, Identity and Performance. Contemporary Theatre Review, Volume 17: 335-345.

Schechner, R. (2006) Performance Studies. An Introduction (Second Edition). Routledge: New York and London.

Sloterdijk, P. (2011) Spheres. Volume 1: Bubbles. Microspherology. Semiotext(e): Los Angeles, California (USA). 
Weitz, R. (1998) The Social construction of Women's Bodies. New York: Oxford University Press

\section{OTHER REFERENCES}

La Fura dels Baus www.lafura.com

Teatro Oficina. Uzona Uzyna http://teatroficina.com.br

'Suz o Suz', Nuevo ejercicio de La Fura del Baus sobre la violencia. La Vanguardia, $1 / 09 / 1985$

La Fura monta el pollo. El Pais, 15.10.1996

Fuerza Artística de Choque Comunicativo (Artistic Force of Communicative Shock, or FACC)

http://www.stylist.co.uk/people/women-naked-screaming-protest-performance-

argentina-buenos-aires-facc-niunamenos

\section{VIDEO RECORDINGS}

Macumba Antropofaga, Teatro Oficina

https://www.youtube.com/watch?v=2OVIYNYG7wU\&list=PL37F48700549FDED8

Die Walkure. La Fura dels Baus.

https://www.youtube.com/watch?v=rp8XDtUt0q8

Degustación de Titus Andronicus. La Fura dels Baus.

https://www.youtube.com/watch?v=wA28vXtHT98

Suz o suz (1985) La Fura dels Baus

https://www.youtube.com/watch?v=q3UbtCtCJU0 